\title{
O SUPER CORPO NEGRO: A REPRESENTAÇÃO DO LUTADOR ANDERSON SILVA, NO COMERCIAL THE GREAT PREPARATION, DA CERVEJA BUDWEISER
}

The super black body: the representation of fighter Anderson Silva, in commercial The great preparation, from the brewery Budweiser

El súper cuerpo negro: la representación el luchador Anderson Silva, en la publicidad The great preparation de la cervecería Budweiser

Sônia Guazina

Relações Públicas pela Universidade Federal de Santa Maria soniac.guazina@gmail.com

Isabel Padilha Guimarães

Professora da Universidade Federal de Pelotas guimaraesisabel3@gmail.com

\section{Resumo}

$\mathrm{O}$ artigo tem por objetivo a análise da representação do negro na publicidade, tratado como um super corpo, atribuído devido às suas qualidades físicas, utilizando como objeto de estudo, o filme publicitário The Great Preparation, da cerveja Budweiser, protagonizado pelo lutador Anderson Silva. Trata-se de um recorte específico do aspecto relativo à representação midiática do negro na publicidade deste comercial. Se busca compreender a relação dos elementos culturais e imagéticos que conduzem à representação do super corpo no comercial citado. O método utilizado será a análise fílmica, proposta por Aneas (2013), que estuda a relação entre a dimensão fílmica e a dimensão promocional de um filme publicitário.

Palavras-chave: Estereótipo. Negro. Corpo.

\begin{abstract}
The objective of this research is to analyze the representation of Black people in advertising, treated as a super body, due to their physical qualities, using as study object the publicity film The Great Preparation, of Budweiser beer, casted by the fighter Anderson Silva. The aim is to understand the relation of cultural and image elements that lead to the representation of the super body in the mentioned commercial. The method used will be the filmic analysis, by Aneas (2013), which study the relation between filmic dimension and the promotional dimensional of a publicity film.
\end{abstract}

Key words: Stereotype. Black People. Body. 


\section{Resumen}

La investigación tiene como objetivo la analice de la representación del negro en la publicidad presentado como súper cuerpo, atribuido debido a sus calidades físicas, utilizadas como objeto de investigación, en la película publicitaria The Great Preparation de la cervecería Budweiser, protagonizada por el luchador Anderson Silva. Tratase de un recorte específico del aspecto relativo a la representación mediática del negro en esta determinada publicidad. Se busca comprender la relación de los elementos culturares e imaginéticos que conducen con la representación del súper cuerpo en el dicho comercial. El método de investigación será la analice fílmica (analice de películas), la cual considera la abordaje metodológica propuesta por Aneas (2013) que estudia la relación entre la dimensión fílmica y la dimensión promocional de una película publicitaria.

Palabras clave: Estereotipo. Negro. Cuerpo.

\section{INTRODUÇÃO}

O ser humano difere-se dos outros seres vivos pelo simbolismo que dá as suas manifestações, crenças e ideologias e pelos sentidos que atribui às relações humanas e sociais, as quais está submetido. E a comunicação é o meio imprescindível para manutenção das relações humanas, pois perpassa por diversos campos dos saberes sociais, políticos e culturais. Conforme Morais (2005, p.69), "a comunicação deve ser entendida como a colocação em comum de sentido da vida e da sociedade".

Neste sentido, as tecnologias de informação e a mídia contribuem para a construção das identidades individuais e coletivas. Daí a importância de se decifrar os textos comunicacionais, uma vez que estes constroem e validam o que é ou não aceitável para os diferentes atores sociais.

É importante compreender a comunicação como fomentadora de sentido, principalmente nas imbricações de caráter ideológico, como por exemplo, o estereótipo. $\mathrm{Na}$ sociedade ocidental e midiatizada, o estereótipo torna-se um grande aliado na legitimação da discriminação, do racismo e do preconceito. "La pregnancia de los estereotipos lleva con frecuencia a un círculo vicioso". (PIERROT e AMOSSY, 1997, p.42). Sendo assim, o estereótipo é uma ideia preconcebida sobre determinados grupos e/ou indivíduos, promovendo o outro de forma distinta do eu. Logo este outro pode ser visto como menos importante, desprovido de qualidades e competências. Segundo Stuart Hall (2003, p.337), "não há nada que o pós-modernismo global mais adore do que um certo tipo de diferença: um toque de etnicidade, um 'sabor' do exótico e, como dizemos em inglês, a bit of the other (expressão que no Reino Unido possui não só uma conotação étnica, como também sexual)”. 
Temas como a consequência da escravatura no Brasil e o racismo geram mal estar e constrangimento, pois há uma enorme negação em torno destas questões, uma vez que a sociedade brasileira é visivelmente miscigenada e, portanto, existe a ideia de superação desta problemática. Porém, o que se observa, é um déficit de compreensão e a falta de debate em relação às questões nas quais a temática é o negro, fazendo com que o racismo permaneça como algo natural, pois há uma confusão entre democracia e tolerância raciais.

A constatação de tal realidade impõe a necessidade de rastreamento das práticas racistas, que nem sempre se traduzem pelo ódio explícito à diferença étnica. Seus dispositivos são acionados, muitas vezes, de modo automatizado, naturalizado, quase silencioso, dificultando a identificação e o combate ao fenômeno (ANDI: IMPRENSA E RACISMO, 2012, p.7).

Sabe-se que a raça negra é corriqueiramente estereotipada, na sociedade midiatizada, pois permanecem no Brasil ideologias racistas como o mito da Democracia Racial ${ }^{1}$ e a Ideologia do Branqueamento ${ }^{2}$, que mesmo após a abolição da escravatura, ainda vigoram de modo camuflado na sociedade. "Nos séc. XVIII e XIX as representações populares da vida cotidiana sobre a escravidão, posse e servidão são tão "naturais" que não requerem qualquer comentário. Fazia parte da ordem natural das coisas" 3" (tradução nossa) (HALL, 1997, p. 245). Diante disto, notamos que a noção racial observada desta maneira, possui uma conotação política e social utilizada "nas relações sociais brasileiras, para informar como determinadas características físicas, como cor da pele, tipo de cabelo, entre outras, influenciam, interferem e até mesmo determina o destino e o lugar social dos sujeitos no interior da sociedade brasileira” (TERUYA; FELIPE, 2008, p. 4).

Observa-se que nas representações midiáticas do uso do corpo negro na publicidade, este é visto como super humano ou como um corpo extremamente hábil, onde a aptidão esportiva é extraordinária, pois, "se por um lado a publicidade não é responsável pela existência do racismo, por outro, ela é uma poderosa arma para a manutenção ou remoção do mesmo". (CORRÊA, 2006, p.57).

\footnotetext{
${ }^{1} \mathrm{O}$ mito da democracia racial tem como finalidade à manutenção do status quo. Logo, as problemáticas e condições dos negros e/ou indígenas são camufladas socialmente, pois remetem aos indivíduos a concepção da superação destas problemáticas, uma vez que o Brasil é visivelmente miscigenado.

${ }^{2}$ Desenvolvida entre os séculos XIX e XX, a ideologia do branqueamento tem como alicerce a mestiçagem étnica e cultural, isto é, encontrar uma unidade social, seja a partir da miscigenação de grupos, assimilação da cultura, modos e valores. Há sempre o conceito de monoetnicidade e monoculturalismo tendo como padrão ideológico, biológico e cultural o homem branco europeu.

${ }^{3}$ No original: in the eighteenth and nineteenth centuries popular representations of daily life under slavery, ownership and servitude are shown as so 'natural' that they require no comment. Is was part of the natural order of things.
} 
Assim, o objetivo deste artigo é analisar a representação da identidade negra do lutador Anderson Silva, em um comercial da cerveja Budweiser, intitulado The Great Preparation ${ }^{4}$, a partir das categorias do estereótipo e dos sistemas binários de representação. Levaremos em conta também, o uso do corpo, pois é através dele que nos relacionamos, nos inserimos, sentimos, percebemos e somos entendidos na e pela sociedade. Abordaremos o trajeto metodológico, que se refere à análise da imagem na publicidade e a representação do negro na publicidade, utilizando os autores Stuart Hall e Pierrot e Amossy e seus estudos sobre o estereótipo, bem como textos que abarcam a temática sobre a mídia e o negro.

Além disso, objetiva-se descobrir se o super corpo produz e fomenta um novo modo de "ver" e "ser" do negro na sociedade brasileira e se há, na sua representação, o início da libertação das ideologias racistas tão enraizadas e promovidas na sociedade brasileira.

No comercial da cerveja Budweiser, o atleta Anderson Silva, maior campeão dos pesos médio de lutas marciais do Ultimate Fighting Championship/ Mixed Martial Arts (UFC/MMA) ${ }^{5}$, ameaça duelar com ator hollywoodiano, Steven Seagel, por uma garrafa de cerveja. Porém, instantes antes do confronto e ao encarar seu oponente, o lutador recorda-se dos seus treinamentos e ensinamentos, os quais são uma paródia dos filmes mais famosos de lutas marciais. O comercial, de um minuto e meio, intitulado The Great Preparation faz parte da campanha de penetração de mercado da cerveja Budweiser e foi lançado em 18 de maio de 2012. Anderson Silva legitimou-se como figura de sucesso tanto dentro do octógono, quanto fora dele. A notoriedade do esportista é mundial e grandes empresas vinculam seus produtos e/ou serviços à imagem do atleta ${ }^{6}$.

\footnotetext{
${ }^{4}$ Comercial The Great Preparation. Disponível em: <http://www.youtube.com/watch?v=4hUDUU2GD6I > Acesso em: 20 nov. 2013. A produção do comercial foi realizada pela agência brasileira Africa, do empresário Nizan Guanaes e a direção, pelo premiado diretor argentino Armando Bo (diretor do filme Biutiful, indicado ao Oscar de Melhor Filme Estrangeiro, em 2011). O comercial, até o início de dezembro de 2013, alcançou a marca de onze milhões e setecentas mil visualizações no canal de vídeos youtube.

${ }^{5}$ O Ultimate Fighting Championship é uma organização americana de Mixed Martial Art, onde lutadores usam diferentes modalidades para competir. Atualmente é o maior torneio de artes marciais no mundo e está estimado em mais de um bilhão de dólares.

6 Anderson Silva foi flagrado em exame antidoping feito no dia 9/01/2015 por uso de drostanolona e androsterona, dois esteroides anabolizantes. No dia 31/01/2015, após a vitória sobre Nick Diaz no UFC 183, outro exame também acusou positivo, por uso de ansiolíticos (temazepam e oxazepam), usados como calmantes e no combate à ansiedade, e novamente drostanolona. O caso ainda não foi julgado. Disponível em:

$<$ http://sportv.globo.com/site/combate/noticia/2015/04/reuniao-que-pode-definir-punicao-de-anderson-silva-emarcada-para-2104.htm >. Acesso em: 06 de abril de 2014.
} 


\section{A IMAGEM NA PUBLICIDADE}

O papel fundamental da publicidade é a propagação e corroboração de ideias, informações e valores. Conforme Sant'Anna (2002, p. 81) "publicidade deriva de público (do latim publicus) e designa a qualidade do que é público. Significa o ato de vulgarizar, de tornar público um fato, uma ideia". Portanto, consideramos a publicidade como um meio de propagação de informações sobre determinados produtos e/ou serviços, tendo como objetivo despertar o interesse e o desejo pelo coisa anunciada. "A publicidade está situada entre a produção e o consumo. Para operar essa mediação, o discurso publicitário se vale, muitas vezes, da linguagem da sedução”. (CORRÊA, 2006, p.7). À vista disso, a publicidade de um produto tem como finalidade divulgá-lo e apresentá-lo à sociedade de modo eficaz, gerando interesse e desejo. Consideramos comercial como sinônimo de propaganda, já que:

(...) a propaganda interpela os indivíduos e os convida-os a identificar-se com produtos, imagens e comportamentos. Apresenta uma imagem utópica de novidade, sedução, sucesso e prestigio mediante a compra de certos bens. (...) Por conseguinte, os indivíduos aprendem a identificar-se com valores, modelos e comportamentos sociais através da propaganda, que é, portanto, um importante instrumento de socialização, ao mesmo tempo em que determina a demanda do consumidor. (KELLNER, 2001. p. 322).

Anteriormente, os comerciais estavam localizados nos intervalos das programações televisivas. Porém, com o surgimento da internet, o comercial passou a ser veiculado também, nas mídias sociais digitais, pois consegue-se absorver o formato audiovisual do comercial e este não perde a sua essência, mesmo sendo transmitido pelas novas tecnologias de informação. "O discurso publicitário fala sobre o mundo, sua ideologia é uma forma básica de controle social, categoriza e ordena o universo. Hierarquiza e classifica produtos e grupos sociais, faz do consumo um projeto de vida" (ROCHA, 1990, p. 26).

As representações audiovisuais na publicidade são construídas de acordo com diferentes objetivos promocionais. Conforme Aneas (2013, p.113), aí reside o aspecto da dimensão fílmica do fílme publicitário: "Os modos de construir e encenar composições audiovisuais". E as maneiras como isso pode se realizar são muitas.

Em se tratando de matéria fílmica, este maquinário que estrutura o comercial é arquitetado com base em formas narradas a partir de recursos imagéticos e sonoros que, normalmente, apresentam personagens em ação. E é neste aspecto que o filme publicitário se aproxima de seus parentes audiovisuais (ANEAS, 2013, p.114). 
O comercial também cria um universo ficcional e, neste sentido, são inúmeras as formas de arquitetar estratégias para a sua realização, através do uso de imagens e sons. Observa-se que o comercial The Great Preparation leva em conta os propósitos promocionais operando a partir de estratégias fílmicas. Neste sentido, uma análise do comercial, sob esta perspectiva, "não deve prescindir da observação das relações entre a dimensão fílmica e o aspecto promocional do filme publicitário" (ANEAS, 2013, p.122). Assim, utilizamos a abordagem metodológica proposta por Aneas (2013), que estuda relação entre a dimensão fílmica e a dimensão promocional de um filme publicitário.

Em uma primeira observação, nota-se que a percepção da marca, no filme analisado, se dá através do predomínio da narrativa, através da reconstituição de famosas cenas de filmes de artes marciais. Neste caso, “a dimensão fílmica é mais relevante do que a promocional, uma vez que a própria estratégia de promoção da marca passa pela oferta de uma peça de entretenimento" (ANEAS, 2013, p.123). O comercial introduz, nas cenas consagradas de filmes de lutas marciais, as garrafas de cerveja Budweiser, em situações que contribuem para o desenvolvimento corporal do atleta. Logo, o corpo exprime a ideia de tempo e espaço, pois apresenta o lugar e a posição do indivíduo na sociedade. O corpo é o reflexo da conjuntura histórica, identitária, cultural e relacional dos indivíduos. Assim, corrobora-se a afirmação de Pereira e Gomes (2001, p. 219):

É no corpo que os homens comunicam seu pertencimento a grupos étnicos distintos, bem como os conflitos decorrentes dessas distinções. Na estrutura física do corpo pode-se ler concretamente as conseqüências de modelos econômicos que produzem a miséria ou o bem-estar dos indivíduos: as feridas, os odores agradáveis o desagradáveis, a vestimenta rota ou elegante são verbos de uma comunicação acerca do processo de exclusão ou de inserção dos indivíduos na sociedade.

Para a análise das cenas do comercial proposto, descreveremos as imagens, transpondo para linguagem verbal, os elementos de informação e de significação que elas contêm. Foi realizada uma decomposição das cenas que foram descritas e interpretadas. O filme objetiva promover uma marca de cerveja e isso não é negado, mas o foco recai sobre o personagem Anderson Silva e como os elementos presentes, como cenário, ambientação e outros personagens contribuem para a sua representação. 


\section{A REPRESENTAÇÃO DO ESTEREÓTIPO DO NEGRO}

A comunicação produz, por meio do estereótipo, valores, sistemas de ideias e histórias, que originam, na sociedade, preconceitos e racismo em relação a determinados grupos e/ou classes sociais, ou seja, o estereótipo não leva em conta o caráter histórico, identitário e cultural do outro.

Reside na força da ambivalência dar ao estereótipo colonial sua atual forma de ser: assegura sua repetição ao mudar as conjunturas históricas e discursivas: informa suas estratégias de individualismo e marginalização: produz este efeito de verdade provável e de predicabilidade que, no caso do estereótipo, deve aparecer sempre em excesso, mais do que ser provado empiricamente ou construído logicamente. (...) (BHABHA, 1992, p. 177-8).

Observamos que o estereótipo se torna uma prática da comunicação, onde o "outro" é alguém marcado como descrente de valores culturais, morais e sociais. De acordo com Stuart Hall (1997, p. 257), “o estereótipo reduz as pessoas a umas poucas características simples, essenciais, que são representadas como fixas pela natureza"7 (tradução nossa). Estas formas são vistas até mesmo como uma maneira predicativa de situar este ser na sociedade, já que o uso do estereótipo promove uma estratégia de participação.

Ele separa o normal e o aceitável do anormal e inaceitável. (...) os estereótipos também são mais rígidos do que os tipos sociais (...) Assim, outro traço de estereótipo é a sua prática de "clausura" e exclusão. Ele simbolicamente estabelece limites e exclui tudo o que não lhe pertence ${ }^{8}$ (tradução nossa) (HALL, 1997, p. 258).

Assim, o negro se vê em uma ambiência desconhecida, cuja finalidade é desconstruir a sua identidade, folclorizar a sua cultura, mais precisamente, relacionando o negro a uma vulgarização animalesca. "Estão relacionados ao negro as características e habilidades 'naturais', como força e sexualidade, enquanto que ao branco cabem atividades 'intelectuais' ou da cultura. Essa é uma relação que se vê repetida em muitas representações estereotipadas ou dizeres do senso comum" (CORRÊA, 2006, p. 7).

\footnotetext{
${ }^{7}$ No original: "stereotyping reduces people to a few, simple, essential characteristics, which are represented as fixed by nature.

${ }^{8}$ No original: stereotyping deploys a strategy of 'splitting'. It divides the normal and the acceptable from the abnormal and the unacceptable. (...) stereotypes are also more rigid than social types (...) so another feature of stereptyping is tts practice of 'clausure' and exclusion. It symbolically fixes boundarles abd excludes everything which does not belong.
} 
A representação do negro na sociedade midiática ainda está vinculada, aos paradigmas escravocratas, uma vez que a sociedade brasileira está enraizada no mito da democracia racial. Um exemplo disto ocorre na publicidade, pois segundo Batista e Leite (2011, p.22), "a publicidade tem sido apontada como agente da exclusão seletiva da população negra, não ocorrendo à utilização de modelos afrodescendestes, nem mesmo na divulgação de produtos de custos reduzidos". Costuma-se acreditar que no Brasil todos são iguais, todos os indivíduos tem os mesmos direitos, acessos e privilégios. No entanto, ao negro não foi dado oportunidades de ascensão social e econômica e, em sua grande maioria, ainda encontram-se enraizados no modelo servil e subalterno de vida, assim como na era escravocrata. De acordo com YIRULA e HOFF (2009, p. 2), quando os escravos foram libertados, encontraram uma sociedade que "carecia de um discurso aberto à democracia racial, o qual, até a atualidade não foi conquistado, e é constantemente confundido com a tolerância racial”. Para um melhor entendimento do que é racismo e como este se manifesta, Hélio Santos (2001, p.85) afirma que "o racismo parte do pressuposto da superioridade de um grupo racial sobre outro, assim como da crença de que determinado grupo possui defeitos de ordem moral e intelectual que lhe são próprios".

O estereotipo dos negros e a sua representação no cotidiano, seja por meio da publicidade/comerciais ou televisão, centraliza uma gama de "tipificações", as quais reduzem seus significados ao fenótipo ou ao caráter biológico. São reforçadas as diferenças entre negros e brancos. Nos primeiros, o foco recai sobre os lábios, o nariz e o corpo rígido, além do cabelo, que geralmente, aparece na mídia, raspado ou enrolado. Aos brancos, a representação não está centralizada apenas na aparência física, pois a estes não são atribuídas somente características fenotípicas, mas também inteligibilidade, racionalidade, moralidade, etc.. "A negritude, enquanto signo, nunca é suficiente. $\mathrm{O}$ que aquele sujeito negro faz, como ele age, como pensa politicamente (...). O ser negro realmente me não basta" (HALL, 2003, p. 347).

No Brasil, esta representação está presente nas novelas nas quais a temática é a escravatura, por exemplo. Atualmente, este estereótipo está ligado ao trabalhador braçal, mordomo, motorista, balconista ou operário. Ou seja, qualquer trabalho no qual não há necessidade de intelecto avançado. Geralmente, estas profissões são representadas por negros, os quais estão uniformizados e em exercício da atividade. Segundo Morais (2005, p. 71): 


\begin{abstract}
Os meios de comunicação constituem um dos dispositivos mais eficazes do "esquema estrutural das diferenças", e isso através dos procedimentos mais opostos. Aqueles que buscam nas outras culturas aquilo que mais se parece com a nossa e para tanto silencia ou adelgaça os traços mais conflitivamente heterogêneos e desafiantes. E para isso não terá outro remédio senão estilizar e banalizar, isto é, simplificar o outro, ou melhor, descomplexizá-lo, torná-lo assimilável sem a necessidade de decifrá-lo. Não é com imagens baratas e esquemáticas dos indígenas, dos negros, que a imensa maioria dos discursos midiáticos, especialmente a televisão, nos aproxima dos outros? Exotiza-se o outro, folcloriza-se o outro em um movimento de afirmação da heterogeneidade que, ao mesmo tempo em que o torna "interessante", o exclui de nosso universo negando-lhe a capacidade de interpelar-nos e questionar-nos.
\end{abstract}

Quando estereotipamos, simplificamos, reduzimos, desvalorizamos aquele indivíduo, negando seus valores culturais, identitários, históricos bem como, os modos de ser e estar. “O estereótipo tem como premissa manter aquele indivíduo e/ou grupo de modo sobrepujado e desfavorecido. Pois, o estereótipo tende a ocorrer onde haja desigualdades gritantes" 9 (tradução nossa) (HALL, 1997, p. 23). Observamos que o ato de estereotipar não somente fortalece as desigualdades, mas também instiga os preconceitos e intolerâncias existentes na sociedade. Ao separar o "eu" do "outro", há uma marca da diferença, a qual não examina o valor histórico e cultural do outro, apenas situa este indivíduo no lugar comum, sem haver um aprendizado prévio e analítico deste.

A representatividade de uma determinada cultura, raça ou grupo, não pode se limitar a um binarismo. Existe uma recusa em ver o outro como seu semelhante, em levar em conta a história, cultura, e os modos de ser deste alheio. Precisa-se de um polo distinto do "eu" para que aquele indivíduo seja marcado como diferente. Esta marcação ocorre por meio do uso do estereótipo e também dos chamados sistemas binários.

Os sistemas binários de representação não levam em conta as características primordiais dos indivíduos, promovendo esquematizações simplistas, cuja propagação se dá por meio da comunicação. Stuart Hall (1997, p. 229) descreve:

\footnotetext{
As pessoas que são de forma significativamente diferentes a maioria "eles" em vez de "nós" - são frequentemente expostos a esta forma binária de representação. Parecem ser representadas através de extremos binários intensamente opostos, polarizados - bom/ruim, civilizado/primitivo, feio/excessivamente atraente, desagradável por ser diferente/coativo por ser
}

\footnotetext{
${ }^{9}$ No original: stereotyping tends to occur where there are gross inequalities of power. 
estranho e exótico. E com frequência exige-se que sejam as duas coisas ao mesmo tempo ${ }^{10}$ ! (tradução nossa).

A sociedade midiatizada está repleta de polarizações binárias, e o discurso hegemônico racista sempre associou as características físicas faciais dos negros à feiúra (cabelo crespo, cor escura, nariz e lábios grossos), mas faz parte do senso comum "admitir" e até ressaltar a beleza do corpo negro. (CORRÊA, 2006, p.6). Neste contexto, notamos que o uso dos sistemas binários auxilia na constituição do estereótipo, pois reduz os significados a um simplismo relacional e social e o auxilia a produzir massivamente um poder moralista sobre determinado grupo, pois ao estereotipar acoberta-se não só o poder de promoção do preconceito, mas também se caracteriza o outro como uma concha de retalhos, cuja tessitura foi amarrada pelo desconhecimento histórico, cultural e identitário deste indivíduo.

Estereotipar não é criar uma imagem falsa que se transforma no bode expiatório das práticas discriminatórias. É um texto muito mais ambivalente de projeção e introjeção de estratégias metafóricas e metonímicas, deslocamentos, causas múltiplas, culpa e agressividade; significa o encobrimento e a ruptura de conhecimentos "oficiais" e fantasmáticos para construir as posições e oposições do discurso racista (HOLLANDA, 1991 p.200).

A imagem é poderosa e assim auxilia na legitimação da diferença de grupos, classes ou raças. Sabemos que os atores sociais são dotados de subjetividade, individualidade e são produtos da cultura e da sociedade nas quais estão inseridas. Não queremos dizer que todos os sujeitos são idênticos, apenas desejemos expor como ocorre a deslegitimação de um grupo, raça e/ou classe social para que outra seja legitimada e, em muitos casos, seja tutora dos grupos desqualificados, os quais sofrem preconceitos.

\footnotetext{
${ }^{10}$ No original: people who are in any way significantly different from the majority- 'them 'rather than 'us`' are frequently exposed to the binary from of representation. They seen to be represented through sharply opposed, polarized, binary extremes- good/bad, civilized/primitive, ugly/excessively attractive , repelling - becausedifferent /compelling -because- strange-and-exotic. And they are often required to be both things of at the same time!
} 
A significação imagética, advinda do uso e poder da imagem carrega um texto subliminar para os atores sociais, porém extremamente encoberto de marcas, estereótipos e sistemas binários. Para Corrêa (2006, p.9), o texto carrega em si as marcas de quem o constrói e de quem o recebe; e a mensagem publicitária é construída de acordo com as idealizações do senso comum para o público ao qual se destina. A maioria das representações do negro na mídia se dá pelo uso libidinoso do corpo. È atribuído aos negros um caráter de extrema sexualidade, e com isso não percebemos um ser humano tal como os demais, mas sim um ser altamente depravado/erótico. Um exemplo disso é a representação da mulata. Os pensamentos que norteiam a imagem da mulher negra, na atualidade, ainda estão alicerçados na esfera escravocrata, na qual ela se torna sinônimo de satisfação e diversão sexual.

A mulher de raça misturada, cruelmente pega entre uma 'herança racial dividida', bonita sexualmente atraente e com frequência, exótica, o protótipo da heroína ardente, sexy, cujo sangue em parte branco se torna 'aceitável', até atraente, para os homens brancos, mas cuja indelével nódoa do sangue negro a condena a um final trágico ${ }^{11}$ (tradução nossa) (HALL, 1997, p. 251).

Há ainda a representação dos "bad bucks - de físico avantajado, fortes, violentos, regenerados, 'sempre em acesso de fúria' altamente sexualizados e selvagens, violentos e enfurecidos desejando sangue de branco". ${ }^{12}$ (tradução nossa) (HALL, 1997, p. 251).

Esse estereótipo fortalece a ideia do negro como primitivo, o qual necessita ser civilizado para socializar-se, já que a selvageria do negro põe em risco a vida em sociedade. Segundo Batista e Leite (2011, p.41):

A mídia hegemônica é etnomídia, pois propaga valores referenciais de uma determinada tipologia humana e é centrada na branquitude normativa. Negros, negras e seus descendentes são colocados na perspectiva de desvio e, portanto, segregados simbolicamente em determinados espaços.

Quando se discorre sobre a temática do negro na sociedade brasileira, usa-se, habitualmente, o conceito de raça ou de etnia. O conceito de raça é entendido como ressignificador, no qual está sujeito a constantes mudanças e concentrações de novos sentidos decorridos das relações humanas e sociais. Estes sentidos têm como finalidade indicar as

\footnotetext{
11 No original: The tragic mulatto - the mixed-race woman, cruelly caught between 'a divided racial inheritance'., beautiful, sexually attractive and often exotic, the prototype of the smoldering, sexy heroine, whose partly white blood makes her 'acceptable', even attractive, to white men, but whose indelible 'stain' of black blood condemns her to a tragic conclusion.

12 No original: bad bucks - physically big, strong, no-good, violent, regenerades, 'on a rampage and full of black rage', 'over-sexed `and savage, violent and frenzied as they lust for white flesh.
} 
diferenças culturais e formações históricas. Durante a década de 1970, o conceito de raça foi ressignificado pelo Movimento Negro Unificado. Neste sentido, é compreendido não no sentido conservador, mas no sentido político. Neste artigo usamos o conceito de raça cunhado por Stuart Hall:

Raça funciona como uma linguagem. E os significantes se referem a sistemas e conceitos da classificação de uma cultura, a suas práticas de produção de sentido. E essas coisas ganham sentido não por causa do que contêm em suas essências, mas por causa das relações mutáveis de diferença que estabelecem com outros conceitos e ideias num campo de significação. Esse sentido, por ser relacional e não essencial, nunca pode ser fixado definitivamente, mas está sujeito a um processo constante de redefinição e apropriação. Está sujeito a um processo de perda de velhos sentidos, apropriação, acúmulo e contração de novos sentidos; a um processo infindável de constante resignificação, no propósito de sinalizar coisas diferentes em diferentes culturas, formações históricas e momentos ${ }^{13}$.

Algumas representações contemporâneas da raça negra na mídia brasileira, aparentemente, concebem o negro como possuidor de um super corpo adaptado aos esportes. Nossa hipótese é de que exemplo disto também ocorre no comercial analisado neste trabalho, da cerveja Budweiser, no qual o campeão mundial dos pesos médios do MMA/UFC, Anderson Silva é retratado como lutador extraordinário, possuidor de habilidades incomuns e de um super corpo, pois possui o domínio das artes marciais, pratica um esporte de luta, considerado violento, em que elementos como a virilidade e a força estão presentes. Conforme Batista e Leite (2011, p. 32):

A exaltação do negro no campo das artes e dos esportes, não obstante o inegável valor e competência dos seus atores serve também como mecanismo de compensação e de limitação dos espaços sociais que esse grupo social deve ocupar, que não são os essenciais na definição dos rumos do país.

\footnotetext{
${ }^{13}$ Stuart Hall. Revista Z Cultural, 2013. Disponível em: < http://revistazcultural.pacc.ufrj.br/raca-o-significanteflutuante>. Acesso em: 31 out. 2013.
} 
Na maioria das vezes, Anderson Silva sai ileso do octógono, o que reforça a ideia de super corpo negro, o qual é apropriado a árduas situações que demandam resistência e força. Somando-se a isso, os lutadores do UFC lutam seminus, o que corrobora com a ideia de sua valorização física. Neste sentido, é primordial analisar esta representação do negro na mídia, para compreendermos se esta visão fomenta estereótipos e ideologias racistas, as quais se encontram vigentes na sociedade contemporânea. De acordo com Stuart Hall (1997, p. 231):

Já está bem definido que os esportes são umas das poucas áreas em que os negros têm sucesso notório. Parece natural que imagens de negros tiradas dos esportes enfatizem o corpo, o que é o instrumento da habilidade e realização atlética. É difícil, no entanto, de ter imagens de corpos em ação, no auge de sua perfeição física, sem aquelas também, de alguma forma, com "mensagens" concernentes ao gênero e à sexualidade ${ }^{14}$. (tradução nossa).

A representação do negro como super corpo na publicidade exalta a superioridade do negro em determinados esportes, como por exemplo, futebol e atletismo. Diante deste contexto, podemos fazer uma analogia em relação ao trabalho braçal realizado pelos negros e a capacidade destes para os esportes, uma vez que a "imagem do escravo forte (muitas vezes comparado a um animal), trabalhador para as lavouras e das minas, serviu também para fazer do negro um ser mais adaptado aos esportes" (MARTINS, 2009, p. 76).

Geralmente, não se observa na representação midiática dos negros, características humanas universais, como por exemplo, inteligência, confiança, valores morais e éticos. Um exemplo disto ocorre na pesquisa de Laura Guimarães Corrêa, De Corpo Presente (2006). Conforme a pesquisadora, a imagem do corpo negro na publicidade brasileira está alicerçada em sete categorias que são o negro assistido (carente e passivo); o negro máquina; o negro gato (um corpo admirável); o negro atleta e músico; o negro risível (um corpo estranho), o negro quase integrado e o negro bem sucedido, que geralmente teve ascensão devido as áreas lúdicas, como o esporte ou música.

\section{ANÁLISE DE THE GREAT PREPARATION}

O filme publicitário, com estilo semelhante aos de faroeste, é protagonizado por Anderson Silva. Ele entra em um inóspito bar e para beber uma cerveja Budweiser, enfrenta a

\footnotetext{
${ }^{14}$ No original: of course, it is well established that sports is one of the few areas where black people have had outstanding success. It seems natural that images of the black people drawn from sport should emphasize the body, which is the instrument of athletic skill and achievement. It is difficult, however, to have images of bodies in action, at th e peak of their physical perfection, without those images also, in some way, carrying 'messages about gender and about sexuality.
} 
ameaça de um duelo com ator hollywoodiano e praticante das artes marciais, Steven Seagal. Porém, instantes antes do confronto, o lutador recorda-se dos treinamentos e ensinamentos, os quais são uma paródia de filmes famosos de lutas marciais.

O comercial inicia com a imagem de um deserto, focando em uma aranha caranguejeira. A imagem da aranha remete ao imaginário do lutador Anderson Silva, pois este é conhecido no universo do Ultimate Fighting Championship (UFC) como the spider, que significa "a aranha", na língua inglesa.

Há também uma trilha sonora de suspense, que transporta o espectador ao imaginário dos filmes de faroeste (Western ${ }^{15}$. Acompanhando os passos da aranha, observa-se o caminhar de uma pessoa, com uma bota em estilo cowboy que caminha em direção a um bar. Além disso, há a presença de uma caminhoneta que está em chamas. O simbolismo do fogo é ambivalente, pois está ligado a características negativas e positivas. De um lado se tem o seu aspecto destruidor, mas de outro, pode ser visto como elemento purificador. No caso, pode-se pensar no aspecto positivo da destruição, porque ao consumir, também aquece e ilumina o sujeito. Este cenário aponta para um local de abandono e perigo, legitimando-se a temática dos filmes em estilo faroeste, insinuando o perigo iminente para reforçar que a violência é a única forma de garantir a segurança individual e social.

Um fator de destaque do gênero faroeste diz respeito ao personagem principal deste estilo cinematográfico: o cowboy, sempre solitário, que geralmente vaga por cenários inóspitos em busca de aventura, mantém a coragem e a tranquilidade e utiliza o recurso da violência apenas quando necessário, isto é, quando alguém o enfrenta ou para manter a ordem diante do caos social. Assim, o cowboy muitas vezes, torna-se um herói.

Um homem é atirado pela janela do estabelecimento e cai desmaiado, enquanto o lutador caminha em direção à porta. Aqui, pode ser traçada uma metáfora em relação às lutas do UFC, como se tratasse de uma luta anterior a de Anderson Silva, pois, normalmente, num evento de UFC, ele é o último a entrar no octógono, com a luta principal. A violência faz parte da vida cotidiana dos personagens dos filmes em estilo faroeste. Marca-se o abandono daquele lugar, pois nem o xerife consegue findar com a barbárie existente. Nos filmes de gênero faroeste, este é ajudado pelo bom cowboy, que desbrava o deserto em busca de aventura, duelando contra os maus cowboys ou bandidos. Deste modo, faz justiça com as

15 Gênero cinematográfico clássico norte-americano, também conhecido como "cinema americano por excelência". Estes filmes fazem uma releitura da colonização do oeste dos Estados Unidos da América (EUA). Western significa "ocidental" e faz referência à fronteira oeste norte-americana, durante época da colonização, que também ficou conhecida como far west "extremo oeste". Deste modo, a nomenclatura provém deste termo. 
próprias mãos, afinal "aquilo que se pensa sobre o mundo e os indivíduos pode tornar-se palpável na superfície do corpo.” (PEREIRA, 2001, p. 221).

Em consequência disso, o personagem principal da narrativa, o bom cowboy, representado por Anderson Silva, torna-se um herói, pois mesmo que atue sem o consentimento da lei, este ajuda o xerife a manter a ordem contra forasteiros e marginais. Ele possui características distintas dos demais que referem-se ao uso do corpo. Faz-se necessário possuir habilidades como destreza, agilidade, força e ainda, um biotipo privilegiado, pois “corpos representados são fragmentos de significação, que organizam múltiplas construções em diferentes universos culturais" (CORRÊA, 2006, p.5). Neste sentido, as significações do corpo do cowboy assim como as do corpo negro, estão organizadas de forma semelhante. Como possuidores de capacidades distintas, que enaltecem e reforçam o uso da força como característica primordial destes indivíduos. Mesmo que Anderson Silva não lute no comercial, fica subentendida a sua capacidade de duelar, se for preciso.

$\mathrm{Na}$ sequência do comercial, Anderson Silva abre a porta e entra no saloon $^{16}$, ameaçador e com pouca iluminação. Só há homens brancos no local e ele é o único negro. Reforça-se, assim a "estratégia da minoração - os negros e negras sempre são colocados em situações em que aparecem ou solitários, ou como minorias, cercados de brancos" (BATISTA e LEITE, 2011, p.38).

Anderson Silva encara as pessoas que lá se encontram. Ao caminhar em direção ao balcão, escuta-se a música do piano em um ritmo mais intenso e a seguinte frase: Ladies and Gentlemen is time. Esta frase envia o espectador ao imaginário de lutas do UFC, pois além de ser pronunciada por Bruce Buffer, (narrador oficial do UFC), e que no comercial, representa o pianista, trata-se da mesma frase que costuma ser dita na abertura dos eventos de lutas do UFC, indicando, no comercial, que poderá haver um confronto no bar.

A pessoa que está atendendo atrás do balcão é o juiz oficial do UFC, Dan Miragliotta. Mais uma vez, reforça-se o imaginário de lutas, pois estão presentes os principais personagens que compõem o evento do UFC: Anderson Silva, o narrador e o juiz oficial do UFC.

Na sequência, Silva e Seagal pedem uma cerveja e se observa a prateleira onde se encontra a última cerveja Budweiser. Ressaltamos que Steven Seagal é um ator popularmente conhecido, por interpretar, no cinema americano, policial violento ou homem com sede de vingança, que também fazem justiça com as próprias mãos. Assim como nas narrativas em

${ }^{16}$ Saloon: bar típico do Velho Oeste norte-americano. 
estilo faroeste, nos filmes em que o ator atua, a violência é o único meio para a solução das problemáticas cotidianas.

Os únicos personagens que fazem uso da palavra são o juiz do UFC, Bruce Buffer, que interpreta o pianista e o ator hollywoodiano Steven Seagal. Apesar de ser, muitas vezes, ridicularizado por possuir uma voz bastante aguda, Anderson Silva demonstra, por meio do super corpo, performances que resultam em vitórias, no octógono. No comercial, inferimos que Anderson Silva não se expressa verbalmente porque a sua comunicação se da através do uso do corpo. Assim, o esportista se manifesta através da força física ou da sua ameaça e, neste sentido, se torna a sua única forma de comunicação. "Nosso corpo nos pertence muito menos do que costumamos imaginar. Ele pertence ao universo simbólico que habitamos pertence ao Outro: o corpo é formado pela linguagem e depende do lugar social que lhe é atribuído para se constituir" (KEHL, 2003, p. 243). Logo, no comercial analisado, são legitimados estereótipos por meio dos sistemas binários de representação, pois a presença de Anderson Silva como protagonista se justifica devido a sua força como lutador e graças ao seu porte físico. Assim, ele não se comunica verbalmente.

Na continuação, o espectador é transportado para as lembranças do lutador, através das narrativas fílmicas que envolvem as artes marciais, as quais fazem referência aos treinamentos e combates mais famosos sobre as lutas orientais. O comercial apresenta cinco sequências. Cada uma delas apresenta Anderson Silva representando o personagem principal de conhecidos filmes de luta.

Na primeira sequência, o atleta está no Japão. Ele está sentado de joelhos e segura hashis (talheres orientais). Nota-se a sua representação como um lutador oriental. O outro homem, de nacionalidade japonesa, interpretado por Yoshizo Machida (mestre de artes marciais) começa a jogar para o alto, tampas das garrafas que estão sobre a mesa. Observa-se que Anderson recolhe as tampas no ar, utilizando os hashis, demonstrando habilidade e técnica. Este cena do comercial faz referência ao celebre filme Karate Kid (John Gilbert Avildsen, 1984).

A seguir, Anderson Silva surge concentrado, de olhos fechados, fazendo movimentos de karatê com as mãos. Está suspenso no ar, com as pernas abertas e apoiado, apenas, em duas garrafas. Esta cena faz referência ao filme O Grande Dragão Branco (Bloodsport - Newt Arnold, 1988), estrelado pelo ator e lutador Jean Claude Van Damme. Esta cena reforça a habilidade de Silva, já provada na cena anterior, acrescida de incrível equilíbrio. 
$\mathrm{Na}$ terceira sequência, Anderson Silva encontra-se em uma sala repleta de espelhos, Ele dá um grito e chuta um dos inúmeros espelhos da sala. Estilhaços são lançados no ar. Esta cena faz referência ao filme interpretado por Bruce Lee, Operação Dragão (Enter the dragon - 1973), que é considerado, até hoje, o melhor lutador de artes marciais de todos os tempos.

$\mathrm{Na}$ continuação do comercial, Anderson está em um campo coberto de neve. O esportista tem preso aos ombros uma corda e, com ela, puxa engradados de cerveja. Esta cena faz referência ao treinamento do personagem de Sylvester Stallone, no filme Rocky Balboa IV (Sylvester Stallone, 1985). Aqui, o corpo de Anderson, além de aguentar baixas temperaturas, possui força similar a de um animal.

Por fim, vestindo um macacão amarelo ouro e uma peruca loira, ele desce voando do teto de um salão. O lutador segura uma espada Katana (japonesa). Ao aterrissar no salão, Silva corta com a espada o colarinho do chope que está servido. Esta parte do comercial é uma paródia da trilogia Kill Bill Vol. I (Quentin Tarantino, 2003). O personagem que Anderson representa é Beatrix Kiddo, justiceira interpretada na saga de Tarantino por Uma Thurman.

Notamos que Anderson Silva transita pelo imaginário destes filmes, possuindo distintas qualidades relacionadas às artes marciais, tornando-se assim, um super lutador que é dono de um super corpo. Conforme Batista e Leite (2011, p.63): “outra característica do discurso publicitário é a exploração de diversas linguagens sobrepostas, que convergem na busca da potencialização dos efeitos de sentido". Isso pode ser observado no fato do filme publicitário utilizar imagens consagradas no cinema de artes marciais para a sua realização.

Ao interpretar vários tipos de lutadores, em cenas símbolos de lutas marciais, perdemse as características de Anderson Silva, como agente divulgador negro, uma vez que não há nenhuma referência sobre a raça do lutador, mostrando-o como um bom cowboy/lutador, não porque possui qualidades que provém da sua identidade, cultura ou raça ou devido ao seu sucesso no UFC, mas através da representação de outros personagens do universo das lutas.

Após as cenas sobre as paródias dos filmes de artes marciais, retorna-se à imagem de Anderson Silva no bar, com Steven Seagal. Ambos caminham um em direção ao outro. Neste momento, observamos o ápice dos filmes do gênero faroeste, o duelo, no qual a lei do mais forte ou do mais apto impera, tendo sempre a violência ou sua ameaça, como única forma de garantir segurança em uma terra sem lei.

\section{CONSIDERAÇÕES}


Observamos e interpretamos os significados que representam o corpo negro na narrativa e constatamos que o super corpo negro não muda o modo de "ver" e "ser" negro na sociedade, já que esta concepção está aliada a velhos paradigmas racistas. O estereótipo do negro é reforçado no comercial e o corpo negro torna-se um instrumento de entretenimento.

As qualidades físicas do super corpo negro, são representadas no comercial pelos mais consagrados filmes de artes marciais. Essas representações não incluem a identidade do esportista, pois enquanto agente negro ele não representa a sua raça, mas sim, interpreta lutadores orientais, brancos e até mesmo uma mulher.

Percebemos que a representação do corpo negro no comercial, está ligada ao conceito do bom cowboy dos filmes do gênero faroeste. Ou seja, tanto Anderson Silva como os bons cowboys são distintos da maioria e esta distinção se dá pelo uso valorativo do corpo, que é sinônimo de coragem, destreza, força e habilidade. Ademais, nos filmes de faroeste, a lei do mais forte, do mais apto impera e, a vista disto, se faz uma analogia entre os filmes deste gênero e as lutas do UFC, uma vez que, em ambos os espaços, a premissa do mais forte e do mais apto impera e os personagens, cowboys e lutadores, são vistos como melhores e mais qualificados que os demais.

Observamos ainda, que a representação do lutador não leva em conta a identidade negra do esportista, pois Anderson Silva recorda-se dos seus treinamentos sobre as artes marciais e estas recordações fazem referência a filmes onde não há nenhum representante da raça negra. A interpretação de personagens célebres dos mais consagrados filmes sobre artes marciais encobrem e mascaram a sua identidade e somente o uso do corpo negro faz sentido socialmente. Assim não observamos nenhuma nova construção midiática sobre a raça negra.

Uma vez que o corpo é matéria palpável da representação do outro e construto social, torna-se um indicador identitário, cultural e histórico dos indivíduos. A ideia de super corpo negro reforça os estereótipo do senso comum sobre o negro, como por exemplo, o negro máquina, o qual é hábil para atividades que demandem esforço físico em detrimento do intelecto.

Ao interpretar identidades brancas, orientais e femininas, a ideia perpassada pelo comercial é a de que Anderson Silva difere-se dos demais lutadores, pelas representações dessas diversas identidades e não por ser um atleta negro de sucesso. "No caso das propagandas esportivas, os atletas nelas retratados não aparecem como negros, tampouco evocam aspectos étnicos, mas, como dissemos, alcançam uma condição superior justamente 
por se destacarem de seu grupo de origem”. (SOARES, R. L., 2011, p. 158). Portanto, o atleta não é retratado como agente negro, porque é destacado de sua raça, logo, a identidade da raça negra é secundária, ou melhor, inexistente no comercial, já que esta não é representada.

\section{REFERÊNCIAS}

ANDI, Imprensa e Racismo - Uma análise das tendências da cobertura jornalística, 2012. Disponível em: <http://www.andi.org.br/sites/default/files/Imprensa-eRacismo_FINAL_14dez-2012.pdf>Acesso em: 13 set. 2013.

ANEAS, Tatiana Guenaga. Premissas para aplicação de análise fílmica à publicidade audiovisual: um exercício analítico de always woman. Cadernos de Comunicação. V.17, n.18, jan-jun. 2013. Disponível em: < http://cascavel.ufsm.br/revistas/ojs-

2.2.2/index.php/ccomunicacao/article/view/10896 > Acesso em: 10 out. 2013.

BATISTA, Leandro Leonardo. Francisco LEITE. O Negro nos Espaços Publicitários Brasileiros. (Orgs.)., São Paulo: Escola da Comunicação e Arte/USP 2011. Disponível em: $<$ http://pt.slideshare.net/leitefco/e-book-o-negro-nos-espaos-publicitrios-brasileiros-batista-eleite-org-2011> Acesso em: 06 dez. 2013.

BHABHA, Homi. A questão do "outro": diferença, discriminação e o discurso do colonialismo. In: HOLLANDA, Heloísa Buarque de. Pós-modernismo e política. Rio de Janeiro: Rocco, 1992, p. 177-203.

CORRÊA, L. G. De corpo presente: o negro na publicidade em revista. 2006. Dissertação (Mestrado em Comunicação Social) - Universidade Federal de Minas Gerais, 2006.

Corpo exposto e a representação do negro em dois anúncios de telefonia celular. FUMEC, MG, 2006. Disponível em <http://www.unirevista.unisinos.br/_pdf/UNIrev_Correa.PDF>. Acesso em 04 dez. 2013.

FONTOURA, Alexandre Soares da, Hibridismos audiovisuais: as relações de intertextualidade no filme publicitário "the great preparation". 2012 Disponível em: < http://lapecpp.files.wordpress.com/2011/05/alexandre_fontoura.pdf> Acesso em: $01 \mathrm{dez}$. 2013.

HALL. Stuart. Da diáspora: identidades e mediações culturais. Belo Horizonte: UFMG /Brasília: UNESCO, 2003.

. The spectacle of the 'other'. In S. Hall (Ed.). Representation. Culture representations and signifying practices. London: Sage-The Open University, 1997. (pp.223290)

HOLLANDA, Heloisa Buarque (Org). Pós-modernismo e política. Rio de Janeiro: Rocco, 1991.

JOLY. Martine. Introdução à análise da imagem. Campinas, Papirus, 1996. 
KEHL, M. R. As Máquinas Falantes. Termo In: Lira, Bernadette; Santana, Gelson (org.). Corpo \& Mídia. São Paulo: Arte \& Ciência, 2003.

KELLNER, D. A cultura da mídia. Bauru: Edusc, 2001.

MARTINS, Carlos A. M. Racismo anunciado: o negro e a publicidade no Brasil (19852005). São Paulo 2009. Disponível em <http://www.teses.usp.br/teses/disponiveis/27/27154/tde-04042010-182647/pt-br.php>. Acesso em: 15 nov. 2013.

MORAIS, Dênis de. (Org). Por uma outra Comunicação. Rio de Janeiro: Record, 2005.

PEREIRA, Edimilson de Almeida e GOMES, Núbia Pereira de Magalhães. Ardis da Imagem: exclusão e violência nos discursos da cultura brasileira. Belo Horizonte: Mazza Edições/Editora PUC Minas, 2001.

PIERROT, Herschberg, Anne: AMOSSY, Ruth. Stéréotypes Et Clichés: Langue, Discours, Société. Nathan Paris. (1997). In AMOSSY, Ruth; PIERROT, Ane Herschberg. Estereotipos y clichés. Buenos Aires: Eudeba, 2005.

ROCHA, Everardo P. Guimarães. Magia e capitalismo: um estudo antropológico da publicidade. São Paulo: Brasiliense, 1990.

SANT'ANNA, Armando. Propaganda: teoria, técnica e prática. São Paulo: Pioneira Thonson Learning, 2002.

SANTOS, H. A busca de um caminho para o Brasil: a trilha do ciclo vicioso. São Paulo: Ed. Senac, 2001.

SOARES, R. L. . Imaginários e representações: o negro na publicidade televisiva brasileira. In: BATISTA, Leandro Lenardo; LEITE Francisco. (Org.). O negro nos espaços publicitários brasileiros: perspectivas contemporâneas em diálogo. São Paulo (SP): ECAUSP/Cone, 2011, v. 1, p. 149-162.

YIRULA, Carolina Prestes; HOFF, Tânia Márcia Cezar. As representações do negro na publicidade contemporânea: a Campanha de Veja. Intercom - Sociedade Brasileira de Estudos Interdisciplinares da Comunicação XIV Congresso de Ciências da Comunicação na Região Sudeste - Rio de Janeiro - 2009. Disponível em:

<http://www.intercom.org.br/papers/regionais/sudeste2009/resumos/R14-0629-1.pdf> Acesso em: 07 ago. 2012.

ZUIN, Antônio Á. S. O corpo como publicidade ambulante. Perspectiva. Florianópolis, v. 21, n. 01, p. 39-53, jan./jun.2003. Disponível em: <http://www.perspectiva.ufsc.br/perspectiva_2003_01/04_artigo_zuin.pdf >. Acesso em: 30 out. 2013. 
Professora no Curso de Jornalismo da Universidade Federal de Pelotas. Doutora em Comunicação Social pela Pontifícia Universidade Católica Do Rio Grande do Sul (Pucrs).

(a) $\left(\frac{1}{14}\right.$

Esta obra está licenciada sob uma Licença Creative Commons. 